\title{
Physico-Chemical Analysis of Water from Hand- Dug Wells in Wadata Area of Makurdi Metropolis, Nigeria
}

\author{
Asen, N.A.; Aguoru, C. U.; Olasan, J. O and Ogbonna, I.O.
}

Department of Biological Sciences (Environmental Science Unit), Federal University of Agriculture, Makurdi Corresponding Author: lekanolasan@yahoo.com

\begin{abstract}
In many countries around the world, including Nigeria, access to potable water has become a mirage. Thus, exploitation ofgroundwater through the construction of hand-dug wells has become a major source of drinking water for majority of the populace. The need to assess the quality of water from this source has become imperative because of the health impacts on individuals. The physicochemical characteristics of water from 166 hand-dug wells in Wadata area of Makurdi metropolis, Nigeria, were assessed during the dry season of 2017. Chloride $\left(\mathrm{Cl}^{-}\right)$, Nitrate $\left(\mathrm{NO}_{3}^{-}\right), \quad$ Sulphate $\left(\mathrm{SO}_{4}{ }^{2-}\right), \quad$ Ammonium $\left(\mathrm{NH}_{4}{ }^{+}\right)$, Phosphate $\left(\mathrm{PO}_{4}{ }^{3-}\right)$, Total hardness (TH), Total dissolved solids (TDS) and turbidity were determined using standard analytical methods. Sodium ( $\mathrm{Na})$, Calcium (Ca), Magnesium ( $\mathrm{Mg}$ ), and Potassium $(K)$ were determined using Flame Atomic Absorption Spectrophotometer (PG 990 model). As part of the physical parameters, TDSranged from 19.20 to $8932.20 \mathrm{mg} / \mathrm{L}$ while Turbidity also ranged from 1.00 to $12.00 N T U$. Chemical parameters were in the range of: $\mathrm{Cl}^{-}(14.18$ to $751.54 \mathrm{mg} / \mathrm{L}) ; \mathrm{NO}_{3}$ (11.00 to $62050.00 \mathrm{mg} / \mathrm{L}) ; \mathrm{SO}_{4}{ }^{2-}(6.70$ to $321.70 \mathrm{mg} / \mathrm{L})$; $\mathrm{PO}_{4}{ }^{3-}(12.30$ to $1093.25 \mathrm{mg} / \mathrm{L}) ; \mathrm{NH}^{+}(2.60$ to $321.40 \mathrm{mg} / \mathrm{L})$; $\mathrm{TH}(76.80$ to $5467.80 \mathrm{mg} / \mathrm{L})$. Metalloids were in the range of: $\mathrm{Na}(2.90$ to $78.60 \mathrm{mg} / \mathrm{L}) ; \mathrm{Ca}(0.00$ to $654.00 \mathrm{mg} / \mathrm{L}) ; \mathrm{Mg}$ (3.70 to $67.80 \mathrm{mg} / \mathrm{L}) ; \mathrm{K}(4.00$ to $238.00 \mathrm{mg} / \mathrm{L})$.Many hand dug wells in the area are contaminated based on the physicochemical parameters tested as values were above the acceptable limits prescribed by Standard Organization of Nigeria (SON) for drinking water.This information is important to all stakeholders including regulatory authorities in environment and those saddled with the responsibilities of preventing and controlling water borne disease outbreaks.
\end{abstract}

Keywords- Environment, Hand-dung wells, Health, Physicochemical properties Water quality.

\section{INTRODUCTION}

Generally, groundwater, surface water (rivers, streams and ponds), atmospheric water (rain-water, snow) and springs are the main sources of water available to people. The quality of these water bodies vary widely depending on the location and environmental factors [1]. The major source of groundwater is precipitation that infiltrates the ground and moves through the soil and pore spaces of rocks. Other sources include water infiltrating from lakes and streams, recharge ponds and water treatment systems. As groundwater moves through soil sediments and rocks, many impurities such as disease-causing micro-organisms are filtered [2]. In developing countries such as Nigeria many water resources are unhealthy because they contain harmful physical, chemical and biological agents. To maintain good health, water should be safe to drink and meet the local and international standards. To monitor the water resources and ensure sustainability, national and international criteria and guidelines established for water quality are being used [3]. In Benue State, despite efforts made by Government to provide potable water to urban and rural areas, a large percentage of the water supply schemes are malfunctioning, forcing consumers to use unprotected sources that pose health hazards. Annual report from national dailies show marked episodes of epidemic in Wadata area of Makurdi metropolis arising from water problem [4].The trend of uncontrolled and haphazard construction of groundwater facilities, particularly hand-dug wells, in the residential areas with refuse dumps within the vicinity, is a great health concern, as this may contribute significantly to adverse impact on the aquifer as a result of overdependence and over-abstraction with attendant negative effects. To safeguard the health of the residents, it is imperative that the quality of the water from hand-dug wells be ascertained. The overall goal of the study was therefore, to determine the potability of water from the hand-dug wells located in Wadata area of Makurdi metropolis. 


\section{METHODOLOGY}

\section{Study Area}

Makurdi, the study area, is situated on Long $8^{\circ} 10^{1} \mathrm{~N}$ and $8^{\circ}$ $45^{1} \mathrm{~N}$; and Lat. $7^{\circ} 1^{1} \mathrm{E}$ and $7^{\circ} 45^{1} \mathrm{E}$ in the Southern Guinea Savanna of Nigeria. The town is drained by the River Benue which bisects it into two parts - North and South banks. Other minor rivers that drain the town, and in turn empty their water in the River Benue include; Rivers Idye, Genabe, Unudu, Kpege and Kereke [5]. These rivers are highly seasonal and dry up in the dry season with some stagnant pools in their channels in the dry season. Due to the general low relief of Makurdi town, large portions of the area are water-logged and flooded during heavy rainstorm. Two major climate seasons are recognized; the dry season which is between November and March, and the wet season which starts in April and then ends in October with a short break in mid-August. The average annual precipitation is above $220 \mathrm{~mm}$ and serves as a major source of groundwater replenishment. Temperature ranges between $21.3^{\circ} \mathrm{C}$ and $32.8^{\circ} \mathrm{C}[6]$.

\section{Water sampling}

One hundred and sixty-six (166) water samples were collected from the study area (Fig.1), in September, 2016, using multi-stage sampling techniques. Fifty-five (55) samples from protected wells (p); 55 from semi-protected well(s); and 56 from un-protected wells(u), using two-litre rubber bottles which have been previously washed with $10 \%$ nitric acid $\left(\mathrm{HNO}_{3}\right)$ and $1: 1 \mathrm{HCl}$ for 48hours. The rubber bottles were labeled and immediately, few drops of HNO3 were added in order to prevent loss of metals and the growth of any micro-organisms. Turbidity of the water samples were also measured at the time of collection.

\section{Laboratory analysis}

Turbidity and nitrate were determined using direct reading spectrophotometer (DR/2000) made by HACH Company. Total dissolved solids was determined using TDS kid Model 50150 made by HACH. Total water hardness $(\mathrm{TH})$ was determined using Hardness EDTA titration. $\mathrm{Cl}^{-}, \mathrm{NO}_{3}{ }^{-}$, $\mathrm{SO}_{4}{ }^{2-}, \mathrm{PO}_{4}{ }^{3-}$ and $\mathrm{NH}_{4}{ }^{+}$ions were determined using standard analytical methods. Metalloids: $\mathrm{Na}, \mathrm{Ca}, \mathrm{Mg}, \mathrm{K}$ were determined using Atomic Absorption Spectrophotometer (ASS) Model PG 990. All instruments were calibrated before use.

\section{RESULTS AND DISCUSSIONS}

Table 1 presents the total dissolved solids, hardness and turbidity of water samples. Total dissolved solids (TDS) ranged from 19.20 to $8932.20 \mathrm{mg} / \mathrm{L}$ with a mean of 540.48 $\mathrm{mg} / \mathrm{L}$. TDS values were above permissible level of $500 \mathrm{mg} / \mathrm{l}$ by SON, for drinking water. The high values observed may be as a result of intrusion or runoff of wastes from the surroundings into the wells $[7,8,9]$. Turbidity ranged from 1.00 to $12.00 \mathrm{NTU}$ with a mean of 4.67 NTU. Turbidity positively correlated with TDS, sulphate and phosphate. High turbidity may be as result of runoff of wastes from the surroundings which increased the amount of dissolved solids and suspended materials in the water. Total hardness (TH) ranged between $76.80 \mathrm{mg} / \mathrm{L}$ and $5467.80 \mathrm{mg} / \mathrm{L}$ with a mean of $567.08 \mathrm{mg} / \mathrm{L}$. TH exceeded SON threshold of 150 $\mathrm{mg} / \mathrm{L}$ for drinking water. $\mathrm{TH}$ correlated significantly and positively with $\mathrm{Cl}^{-}$and $\mathrm{NO}_{3}{ }^{-}$(at 0.05 level) and $\mathrm{SO}_{4}{ }^{2-}$ (at 0.01 level). High values may be as a result of high chloride, sulphate, and ammonium ions present in the water samples. TH also correlated weakly with $\mathrm{Na}^{+}$and $\mathrm{Ca}^{2+}$. This implies that the presence of these ions in water might have contributed positively to water hardness. The hardness observed in water in the study area may therefore, be permanent hardness. Sodium correlated significantly and positively with nitrate (at 0.05level).This implies that the two ions might have contributed to water hardness. Magnesium correlated significantly and positively with nitrate (at the 0.01 level), implying that the ions might have formed salt in water. $\mathrm{Ca}^{2+}$ correlated significantly and positively with $\mathrm{Cl}^{-}$ions (at 0.05 level), implying that the two ions might have formed salt in the water. Statistical analysis using at 5\% significant level indicated that there was significant variation in total hardness within the wells. High values may be attributed to run-off of materials from the surroundings of the wells which increase the amount of dissolved inorganic materials in the water [10].

Table.1: Total dissolved solids, hardness and turbidityof watersamples

\begin{tabular}{|c|c|c|c|c|c|c|c|}
\hline Water & & & & & & SON & (2007) \\
\hline Parameter & Unit & Min. & Max. & Mean & Std. & Guideline & \\
\hline TDS & $\mathrm{mg} / \mathrm{L}$ & 19.2 & 8932.2 & 540.48 & 765.7 & 500 & \\
\hline Turbidity & NTU & 1 & 12 & 4.67 & 2.67 & 5 & \\
\hline $\mathrm{TH}$ & $\mathrm{mg} / \mathrm{L}$ & 76.8 & 5467.8 & 567.08 & 559.49 & 150 & \\
\hline
\end{tabular}

$\mathrm{TH}=$ Total hardnes ; TDS=Total dis solved solids; SON=Standard organization of Nigeria Min=minimu m; Max=Maximu m; Std=Standard deviation 
Table 2 presents the chloride, nitrate and sulphate contents of water samples from hand-dug wells. Chlorides are usually in water in the form of sodium chloride. This may impact a salty taste to water. When present in concentrations more than $200 \mathrm{mg} / \mathrm{L}$ the taste may be objectionable to some consumers. Results showed that chlorides ranged from $14.18 \mathrm{mg} / 1$ to $751.54 \mathrm{mg} / \mathrm{L}$ with a mean of $246.62 \mathrm{mg} / \mathrm{L}$. Chloride concentration was very high though not all samples exceeded permissible level of $250 \mathrm{mg} / \mathrm{L}$ by SON for drinking water. Statistical analysis at $5 \%$ significant level indicated that there were significant variations in the amount of chloride ions within the wells. The high values observed for standard deviation (std), may be attributed to high variations in the amount of the ions at different sample collection points. The high levels of chloride ions might be attributed to high infiltration of dissolved inorganic substances and runoff during rainy season [9].

Nitrates in water can cause methamoglobinaemia in infants less than six months old [11]. Nitrate ranged between $11.00 \mathrm{mg} / \mathrm{L}$ and $62050.00 \mathrm{mg} / \mathrm{l}$ with a mean of $160.11 \mathrm{mg} / \mathrm{L}$. The level of nitrate ions exceeded the permissible level for drinking water. Thus, babies in the study area may be exposed to serious health hazards. High nitrate concentration observed may be attributed to ingress of animal and human wastes from open septic or sewage systems [7, 8]. Statistical analysis at 5\% significant level indicated that there were significant variations in the concentration of nitrate ions in the water within the wells. The high nitrate concentration may also be attributed to high rate of decomposition of organic materials and infiltration of dissolved compounds[12]. Nitrate ions correlated positively and significantly with total hardness, sodium, and magnesium ions, implying that the presence of nitrate ions in water might have contributed positively to the formation of water hardness [10]. Sulphate is an important constituent of hardness with $\mathrm{Ca}$ and $\mathrm{Mg}$. At concentrations above $300 \mathrm{mg} / \mathrm{L}$, sulphate produces an objectionable taste and unwanted laxative effects in water. Sulphate ranged between $6.70 \mathrm{mg} / \mathrm{L}$ and $321.70 \mathrm{mg} / \mathrm{L}$ with a mean of $63.50 \mathrm{mg} / \mathrm{L}$. These levels are lower than the permitted values set by SON. Statistical analysis at 5\% significant level indicated that there were significant variations of sulphate in water within the wells. The presence of sulphate in the water may be attributed to infiltration of dissolved inorganic compounds into the wells [7].

Table.2: Chloride, nitrate and sulphate contents of water samples from hand-dug wells

\begin{tabular}{lcccccc}
\hline $\begin{array}{l}\text { Water } \\
\text { Parameter }\end{array}$ & Unit & Min. & Max. & Mean & Std. & $\begin{array}{c}\text { SON (2007) } \\
\text { Guideline }\end{array}$ \\
\hline $\mathrm{Cl}^{-}$ & $\mathrm{mg} / \mathrm{L}$ & 14.18 & 751.54 & 246.62 & 136.16 & 250 \\
$\mathrm{NO}_{3}{ }^{-}$ & $\mathrm{mg} / \mathrm{L}$ & 11 & 62050 & 160.11 & 128.5 & 50 \\
$\mathrm{SO}_{4}{ }^{2-}$ & $\mathrm{mg} / \mathrm{L}$ & 6.7 & 321.7 & 63.5 & 64.11 & 100 \\
\hline
\end{tabular}

$\mathrm{SON}=$ Standard organization of Nigeria; Min=minimu m; Max=Maximum; Std=Standard deviation

Table 3 describes the phosphate and ammonium contents of water samples from the hand-dug wells.Phosphate ranged between $12.30 \mathrm{mg} / \mathrm{L}$ and $1093.25 \mathrm{mg} / \mathrm{L}$ with a mean of $189.99 \mathrm{mg} / \mathrm{L}$. The high value of standard deviation may be as a result of variation in the values observed from different sample collection points. The level of phosphate ions exceeded SON threshold for drinking water. Statistical analysis at $5 \%$ significant level indicated that there were significant variationsin phosphate ions in water within the wells. The high values of phosphate may be as a result of decomposition of organic matter and from runoff, surface catchment and interactions between water and sediments from dead plants and animals that remained at the bottom of the wells. Ammonium ranged between $2.60 \mathrm{mg} / \mathrm{L}$ and $321.40 \mathrm{mg} / \mathrm{L}$ with a mean of $44.20 \mathrm{mg} / \mathrm{L}$. The values exceeded SON threshold for drinking water. Statistical analysis at $5 \%$ significant level indicated that there were significant variations in the level of ammonium ions in water within the wells. The high values observed may be as a result of decomposition of organic matter from the surroundings and runoff water which infiltrated the wells [7].

Table.3: Phosphate and ammonium contents of water samples from hand-dug wells

\begin{tabular}{ccccccc}
\hline Water Parameter & Unit & Min. & Max. & Mean & Std. & SON (2007) Guideline \\
\hline $\mathrm{PO}_{4}{ }^{3-}$ & $\mathrm{mg} / \mathrm{L}$ & 12.3 & 1093.25 & 189.99 & 174.5 & 5 \\
$\mathrm{NH}_{4}{ }^{+}$ & $\mathrm{mg} / \mathrm{L}$ & 2.6 & 321.4 & 44.2 & 31.01 & $<1.00$ \\
\hline
\end{tabular}

$\mathrm{SON}=$ Standard organization of Nigeria; Min=minimu m; Max=Maximu m; Std=Standard deviation 
Table 4 presents the sodium, calcium, magnesium and potassium contents of water samples. The values of sodium ions ranged from $2.90 \mathrm{mg} / \mathrm{L}$ to $78.60 \mathrm{mg} / \mathrm{L}$ with a mean of $10.19 \mathrm{mg} / \mathrm{l}$. The level of sodium ions did not exceed SON threshold for drinking water. Statistical analysis at $5 \%$ significant level indicated that there were significant variations in the amount of sodium in water within the wells. Sodium ions in water can cause water hardness.The values of calcium ranged between $0.0 \mathrm{mg} / 1$ and $654.00 \mathrm{mg} / \mathrm{L}$ with a mean of $213.90 \mathrm{mg} / \mathrm{L}$. Calcium ions exceeded WHO standards $(50 \mathrm{mg} / \mathrm{L})$ for drinking water. Statistical analysis at 5\% significant level indicated that there were significant variations in the level of calcium ions in the water within the wells. Magnesiumions showed a range of $3.70 \mathrm{mg} / \mathrm{L}$ and
$67.80 \mathrm{mg} / \mathrm{L}$ with a mean of $10.72 \mathrm{mg} / \mathrm{L}$. The results showed magnesium levels above standards by SON. Statistical analysis at $5 \%$ significant level indicated that there were significant differences in the level of magnesium ions in water within the wells. The presence of $\mathrm{Mg}$ ions in water may be attributed to runoff and infiltration of dissolved materials from the surroundings. Potassium showed a range of $4.00 \mathrm{mg} / \mathrm{L}$ to $238.00 \mathrm{mg} / \mathrm{L}$ with a mean of $75.72 \mathrm{mg} / \mathrm{L}$. The levels are above WHO standards (1-2mg/L) for drinking water. Statistical analysis at 5\% significant level indicated that there was no significant difference within the wells. The presence of $\mathrm{K}$ ions in water may be attributed to runoff and infiltration of dissolved waste materials from the surrounding dumpsite.

Table.4: Sodium, calcium, magnesium and potassium contents of water samples

\begin{tabular}{ccccccc}
\hline $\begin{array}{l}\text { Water } \\
\text { Parameter }\end{array}$ & Unit & Min. & Max. & Mean & Std. & $\begin{array}{c}\text { SON (2007) } \\
\text { Guideline }\end{array}$ \\
\hline $\mathrm{Na}$ & $\mathrm{mg} / \mathrm{L}$ & 2.9 & 78.6 & 10.19 & 8.79 & 200 \\
$\mathrm{Ca}$ & $\mathrm{mg} / \mathrm{L}$ & 0 & 654 & 213.9 & 164.86 & 100 \\
$\mathrm{Mg}$ & $\mathrm{mg} / \mathrm{L}$ & 3.7 & 67.8 & 10.72 & 6.14 & 0.2 \\
$\mathrm{~K}$ & $\mathrm{mg} / \mathrm{L}$ & 4 & 238 & 75.72 & 41.82 & 10 \\
\hline
\end{tabular}

$\mathrm{SON}=$ Standard organization of Nigeria; Min=minimu m; Max=Maximu m; Std=Standard deviation

Figure 1 clearly compared the mean values of water parameters and SON minimum threshold as standards. Based on this, average nitrates, phosphates, ammonium, total hardness, calcium, potassium and ammonium contents in water samples were above the SON limits. Average turbidity, chloride, sulphide, magnesium and sodium were still within or lower than the minimum threshold.

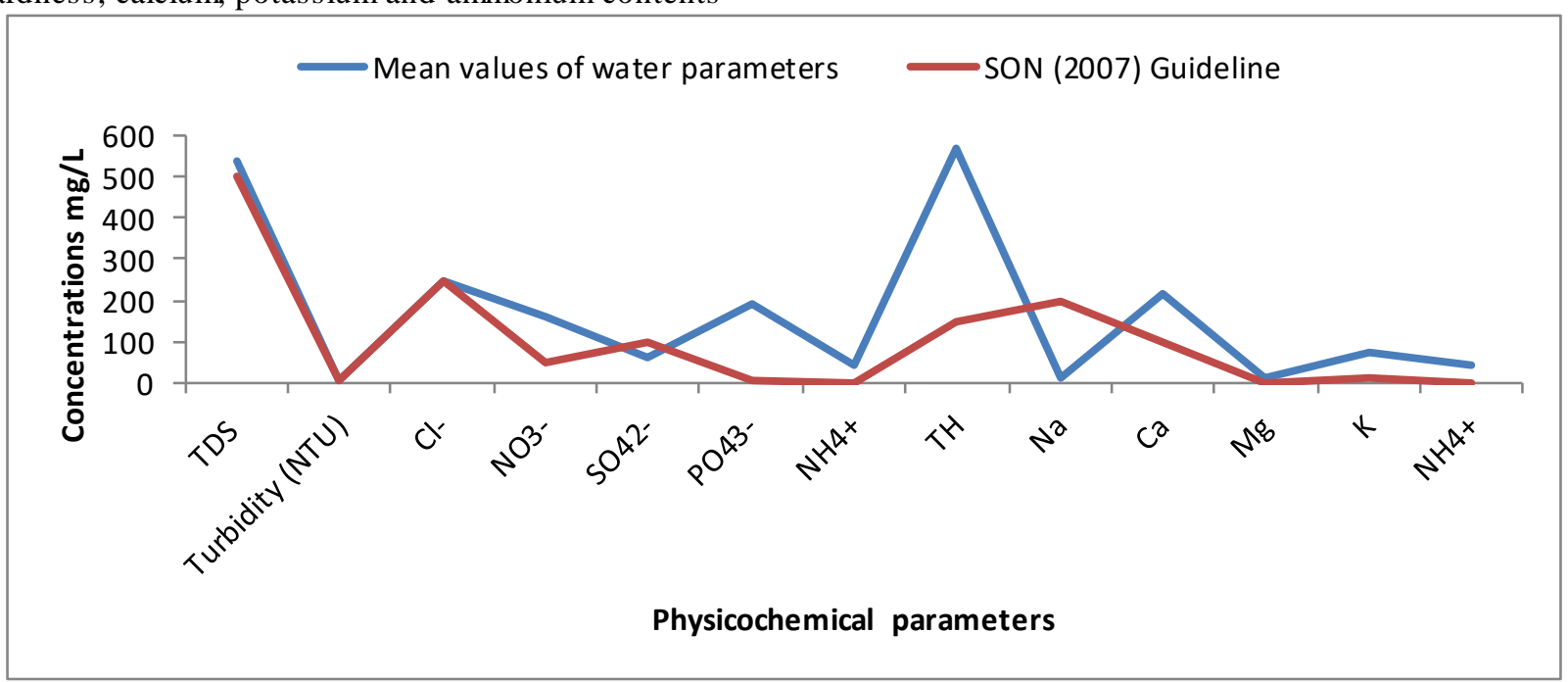

Fig.1: Line plot of mean water parameters and SON standard guideline

$\mathrm{SON}=$ Standard organization of Nigeria

\section{CONCLUSIONS}

The overall results showed that the water from the hand-dug wells is contaminated with the physical and chemical parameters analyzed. The water is therefore, not safe for drinking, cooking and laundry purposes. The inhabitants are therefore, at risk of harmful chemical ions in water which may lead to endocrinal damage, dental decay or dental caries in babies, oxygen starvation in the brain of infants 
leading to 'blue baby' syndrome, kidney or gall bladder stones, disruption of heart and muscular function, water hardness and irritation of the mucous membranes. The need to reduce contamination has a direct relationship with contraction of harmful chemical ions which may lead to water-borne diseases. To achieve this, there is the need to treat the well water before use, either by boiling and filtration or by chemical sterilization or both. Periodic water quality monitoring and incorporation of household water treatment practices with hand-dug well water are recommended. Improved sanitation and hygiene practices by the residents in the area are indispensable.

\section{REFERENCES}

[1] Adetunde, L. A, Glover, R. I. K and Oguntola, G. (2011). Assessment of the groundwater quality in Ogbomosho Township of Oyo State of Nigeria. IJRR 8(1).

[2] Freeze R. A andCherry J. A(1979).Groundwater. Eaglewood Clif N J Prentice-Hale.

[3] WHO (2006). Guidelines for Drinking Water Quality.First addendum to $2^{\text {nd }}$ ed.Geneva.p.595.

[4] Ayado, Solomon (Feb.4, 2014). Fresh Cholera outbreak kills 30 in Makurdi. Leadership Newspaper, p.1.

[5] Ahile, S. I; Udoumoh E. F; and Adzande, P.(2015). Residents coping Strategies with Water Scarcity in Makurdi Town, Nigeria. Mediterranean Journal of Social Sciences, 6(4): 2039-2117.

[6] Aguoru, C. U. and Alu,C. A. (2015). Studies on solid waste disposal management methods in Makurdi and its environs.North Central Nigeria. Green Journal of Environmental Management and Public Safety. ISSN:2354-2476.

[7] Ocheri, M. I., Mile,I. I. and Obeta,M. C. (2010).Seasonal Variation in Nitrate Levels in Handdug Wells in Makurdi Metropolis. Pakistan Journal of Nutrition, 9: 539-542.

[8] Anhwange, B. A., Agbaji, E. B. and E. C. Gimba(2012). Impact Assessment of Human Activities and Seasonal Variation on River Benue, within Makurdi metropolis. International Journal of Science and Technology, 2(5): 2224 - 3577.

[9] Nwafor, E. K.; Okoye C. J. and Akinbile,O. C. (2013).Seasonal Assessment of Groundwater Quality for Domestic use in Akure Metropolis, Nigeria. Proceedings,Nigerian Sciences conference on water Resources and National Development. In: Mbajiorg, C. C., Obeta, M. C. and Anyanwu, C (Eds), pp33-42.

[10] Ishaku, J. M. and H.I. Ezeigbo (2010).Groundwater Quality Monitoring in Jimeta-Yola Area of North
Easthern Nigeria. Journal of Water Resources, 20(2):1-14.

[11] Ayantobo, O. O,Olawasanya G.O., Idowu, O. A and Eruola, A. O (2012). Water Quality from Hand-dug wells in Ibadan. Proceedings, Nigerian Hydrological Sciences Conference on Hydrology for Disaster Management. Federal University of Agriculture, Abeokuta.

[12] Atobatele, Oluwatosin Ebenezer and Ugwumba, O. Alex (2008).Seasonal Variation in the Phsicochemistryof a small Tropical Reservoir (Aiba Reservoir, Iwo, Osun, Nigeria. African Journal of Biotechnology, 7(12): 1684-5315. 